This is a self-archived - parallel published version of this article in the publication archive of the University of Vaasa. It might differ from the original.

\title{
Value co-creation in multinational enterprises' services marketing at the bottom-of-the-pyramid markets
}

Author(s): Leposky, Tiina; Arslan, Ahmad; Dikova, Desislava

Title: Value co-creation in multinational enterprises' services marketing at the bottom-of-the-pyramid markets

Year: $\quad 2020$

Version: Accepted manuscript

Copyright (C)2020 the Author(s), Palgrave Macmillan, Cham.

\section{Please cite the original version:}

Leposky, T., Arslan, A., Dikova, D., (2020). Value co-creation in multinational enterprises' services marketing at the bottom-ofthe-pyramid markets. In: Marinov M., Marinova S., Larimo J., \& Leposky T. (eds), International business and emerging economy firms (pp. 89-116). Palgrave Studies of Internationalization in Emerging Markets. Palgrave Macmillan, Cham. https://doi.org/10.1007/978-3-030-24482-8_4 


\title{
Value Co-Creation in Multinational Enterprises' Services Marketing at the Bottom-of-the-Pyramid Markets
}

\author{
Tiina Leposky, Ahmad Arslan, and Desislava Dikova
}

\begin{abstract}
This book chapter addresses determinants of value creation by multinational enterprises (MNEs) in the still largely neglected research context of bottom of the pyramid (BoP) markets. Consisting of consumers living below the poverty line, BoP markets exhibit significantly different characteristics compared to the affluent developed or the aspirational emerging markets. Dealing with a wide range of diversity within a market where it is difficult to obtain reliable, generalisable information means that MNEs tend to face challenges upon entering them. Yet, the potential demand offered by BoP markets cannot be ignored and MNE's have shown increasingly that they are willing to innovate market-specific approaches to cater to BoP needs. We discuss the applicability of service-dominant (S-D) logic in subsistence context and identify commitment to the market, strategic CSR, and service quality as key firm level determinants of effective service marketing in BoP markets. We further identify social trust, technological outreach and performance orientation characteristics in target BoP market as key country level determinants. Finally, the book chapter offers a number of academic and managerial implications.
\end{abstract}

Keywords: BOP Markets, Service-Dominant Logic, Multinational Enterprises, Value Creation.

* Tiina Leposky, Assistant Professor, School of Marketing and Communications, University of Vaasa, Finland (Email: tiina.leposky@uva.fi)

** Ahmad Arslan, Senior Research Fellow (International Business), Oulu Business School, University of Oulu, Finland. (Email: ahmad.arslan@oulu.fi)

*** Desislava Dikova, Professor, Vienna University of Economics and Business Administration (WU-Wien), Vienna, Austria. (Email: desislava.dikova@wu.ac.at) 


\section{Introduction}

Western MNEs tend to face a range of problems when they enter BOP markets as their existing models of operations do not fit in those conditions (Rohatynskyj, 2011; Sinkovics et al., 2014). Key among these is their lack of understanding of local conditions, as these can vary significantly not only from the company's home environment but also from other emerging markets, and within the market (Anderson et al., 2010). Stories of failures to appreciate what BoP customers want and need abound from attempts to entice consumers with chocolate chip cookies the size of buttons (Sehgal et al., 2010) to an inability to effectively commercialise products even when they address a recognised issue such as a water purifiers (Seagle and Christensen, 2011).

A crucial requirement for understanding the customers in the notoriously difficult to reach BoP markets is local embeddedness (Ben Letaifa and Reynoso, 2015). The performance of Grameen Bank, the poster child of success in BOP markets, has been credited largely to the idea of being innovative through close informal co-operation with local actors and observation of their everyday practices (Simanis and Hart, 2009). Yet, getting close to customers is no guarantee for success - an initiative by Solae to co-create soy-based products in a programme with local customers was abandoned as unprofitable after it failed to attract a customer base large enough to exceed costs (Simanis and Milstein, 2012). If BoP markets are only accessible for those who live and breathe them as the locals do, it is easy to sympathise with MNEs often choosing to engage them through their philanthropic or corporate social responsibility (CSR) outreach. However, business firms such as MNEs exist to make a profit and in practice tend to focus on how to overcome challenges to generate money (e.g. Karamchandani et al. 2011) rather than on making an impact (e.g. Simanis and Milstein, 2012). Therefore, BoP markets should also be analysed from this perspective by academic researchers.

Value co-creation at the BoP markets has received increasing attention from scholars in the past few years, as engagement and involvement of local actors in development issues is advised. Yet, a recent review found that "very few BOP studies scrutinize or even define" what value co-creation is, or whether it is applicable in BoP context (Nahi, 2016: 427-428). Even fewer are the studies that consider value co-creation at BoP markets as a business logic decision that has strategic importance, even though this is generally accepted in service-dominant (S-D) logic in developed markets. Therefore, we aim to fill this research gap by discussing S-D logic in $\mathrm{BoP}$ context and consequently conceptually addressing determinants of effective marketing 
of services in BOP markets at country and firm levels. Our study contributes to international marketing literature by being one of the first to focus specifically on BOP markets. Furthermore, this study contributes to the understanding of micro-meso-macro level processes in BOP marketing. Understanding the key determinants for effective value creation is expected to help MNEs devise applicable entry and operational strategies as well as create immediate benefits for consumers. Based on a literature review, we have identified both MNE and country level determinants of value creation. MNE determinants discussed in our book chapter include commitment to the market, strategic CSR, and service quality. Later, we also address countrylevel determinants including social trust, technological outreach, and performance orientation.

Our book chapter is structured as follows. After the introduction, we review the theoretical basis of current study chapter from the S-D logic viewpoint. Then, we address MNE and subsidiary specific determinants followed by discussion on target BOP market specific determinants. The book chapter concludes with offering a discussion on implications as well as future research directions.

\section{Theoretical Background}

In S-D logic, value co-creation entails actors who are involved in mutual resource integration and service exchange as a process, which is influenced by institutions and other external parties in a framework of service ecosystems (Vargo and Lusch, 2016). While this view on value cocreation, which essentially elevates all interaction as service exchange, is applicable to all contexts where actors engage in resource integration to gain benefit for themselves and their partners, BoP's have received only a limited amount of the attention provided to value cocreation and the increasing scholarly interest on service science. This may be a by-product of how BoP markets have often been viewed as unprofitable markets (Prahalad, 2011) or as passive aid recipients (Gebauer and Reynoso, 2013): viewpoints hardly compatible with a logic that promotes mutual engagement.

Yet the basic axioms of S-D logic, which emphasise the phenomenological experience of value and the interconnected, systematic nature of co-creation, are well suited for the BoP context. This is apparent in, for example, how resource scarcity and turbulence of the environment in many BoPs force people to make critical value judgments about prioritising their local, costlier store which provides credit during tough times over the cheaper but unreliable chain stores (Viswanathan et al., 2009). It is also echoed in how external networks are proportionately more 
important than in Western markets (Danis et al., 2011), and therefore the service ecosystems potentially much more diverse.

In terms of resource integration, the S-D logic conceptualises resources as operand, which are possessed and acted upon, and operant, which are intangible and active (Vargo and Lusch, 2004). Resource scarcity in BoP markets manifests itself in basic essentials as well as expertise and skills (Arslan et al., 2016), which points to an expected resource imbalance between foreign MNE's and the market actors (Arora and Romijn, 2012). However, companies that strive to create value rather than just push commodities upon the market require marketing capabilities to perform in terms of market intelligence, relationship knowledge and access to networks (Ribeiro et al., 2009). Thus, resource integration between MNE's, who can source firm-level competencies globally from their internal operations, and BoP actors with local micro level relationships and macro level knowledge can result in superior value offers.

This zooming in and out of different levels from a tightly focused micro perspective in service exchanges to broader meso and macro considerations is integral to S-D logic (Vargo, 2011). It is also typical for BoP markets where micro level activities (such as microcredits or access to the electricity grid) can have far reaching macro level consequences in terms of economic development or public health, but cannot be homogenously applied across this vast market place (Scott, 2017; Jebarajakirthy and Lobo, 2015). Conversely, BoP markets are generally sensitive to institutional turmoil as infrastructures in emerging markets are typically heterogeneous (Ghauri, Hadjikhani and Elg, 2015). Therefore, changes at the top level can have ripple effects in what Prahalad $(2005 ; 2012)$ posits as the key factors in creating a capacity for consumption in BoP markets, namely the 4A's of awareness, affordability, access and availability.

The 4A's in Prahalad's study (2012) are an alternative take on the traditional 4P's of the marketing mix and as such are aimed to enable economic activity without necessarily leading to value creation. As BoP markets in the past were often not conceptualised even as market places, much less as sources of knowledge and innovation (Viswanathan and Rosa, 2010), understanding the basic factors that allow poor people to engage in economic transactions can help foreign MNE's to access the markets. A deep commitment to co-creative activities is not necessarily even a requirement for a successful, short-term performance in selling goods and services in BoP markets (Nahi, 2016). Thus, the 4A's are meso level factors that focus on the 
firm's actions in spreading awareness, designing and marketing affordable offers, and planning production and logistics value chains to ensure access and availability.

However, in order to provide solutions that address the fundamental challenges of poverty experienced by customers in BoP markets, service exchanges must entail dialogue, listening and partnership (Arora and Romijn, 2012), stakeholder involvement in multiple levels (Nakata and Weidner, 2012), and a commitment to the service ecosystem as a whole (Ratcliff and Doshi, 2016). Involving individuals and community actors at the micro level and cultural institutions at the macro level means that business activities are evaluated by multiple actors who are empowered to provide input on the final offer and determine their received value in line with S-D logic (Vargo and Lusch, 2017).

Yet drawing a direct line between MNE actions and poverty eradication would be presumptuous, as corporate interests do not always align with altruism (Arora and Romijn, 2012) and poor consumers are often suspicious of companies behaving in a manner seemingly obfuscating their profit-driven motives (Valente and Crane, 2010). To avoid exploitation, incorporating the concepts of social justice and fairness to business exchanges is important and congruent with S-D logic and it's "win-win" marketing approach inherent in the fundamental axioms detailed in the original work (Laczniak and Santos, 2011). In this study, we suggest a micro level concept of affinity to complement the 4A's and expand the inclusiveness of the concepts so not only do they map the firm's actions but also the response from the market actors.

Affinity is required to make the customer want to engage with the company and the offer. As awareness reflects the consumer's knowledge about the solution, and affordability, access and availability the consumer's capability to have and utilise the solution, affinity relates to the consumer's motivation and desire to do so. Creating affinity may be difficult in all markets, as customers are often wary of marketing messages (Sheth and Sisodia, 2012). However, BOP markets can present further complications because consumers do not have equal recourse to legal protection and therefore must be more cautious (Chikweche and Fletcher, 2010). In addition, there is a clear power imbalance between BOP actors and large Western MNEs, which can result in a perception of exploitation (Wood, Pitta and Franzak, 2008). Consequently, service exchanges where the aim is to create solutions that actors value are instrumental in ensuring people are committed to the MNE offers and are not exploited by the MNE's inherent power position. 
While value co-creation takes place within the same narrative as in developed markets, it is shaped by the actors as individuals with access to limited resources and by the socio-cultural institutions surrounding them. Thus, service exchanges do not only take place in the context of service ecosystems but also involve communal actors to a much greater capacity as network partners (Lindeman, 2014). Furthermore, because institutions and infrastructures are typically weak, heterogeneous or non-existent in BoP markets, firms cannot rely on existing channels to ensure the key factors for consumption capacity and a greater firm level engagement is required.

In the next chapter, we will discuss the propositions for effective marketing in BoP markets as enablers of value creation. The propositions are divided into meso level activities from the firm's perspective, and micro-macro level cultural and infrastructural determinants from the country perspective. We have chosen this division to show that determinants are context specific and the interplay between micro-meso-macro levels will influence the results.

\section{Propositions of Determinants for BOP Marketing}

The aim of this chapter is to demonstrate that value co-creation is at the centre of effective services marketing in BOP markets but context specific factors influence how it takes place. A visual representation is provided in Figure 1, where we have adapted the value co-creation model by Vargo and Lusch (2016) to include our propositions (marked P1 - P6) as factors of resource integration and institutional arrangements, which enable the circular motion of the model. Furthermore, we have included accessibility, availability, awareness, affordability and affinity as factors of the service exchange, because the exchange relies on the existence of these attributes to take place. The propositions are all elaborated on further in the following subchapters. 


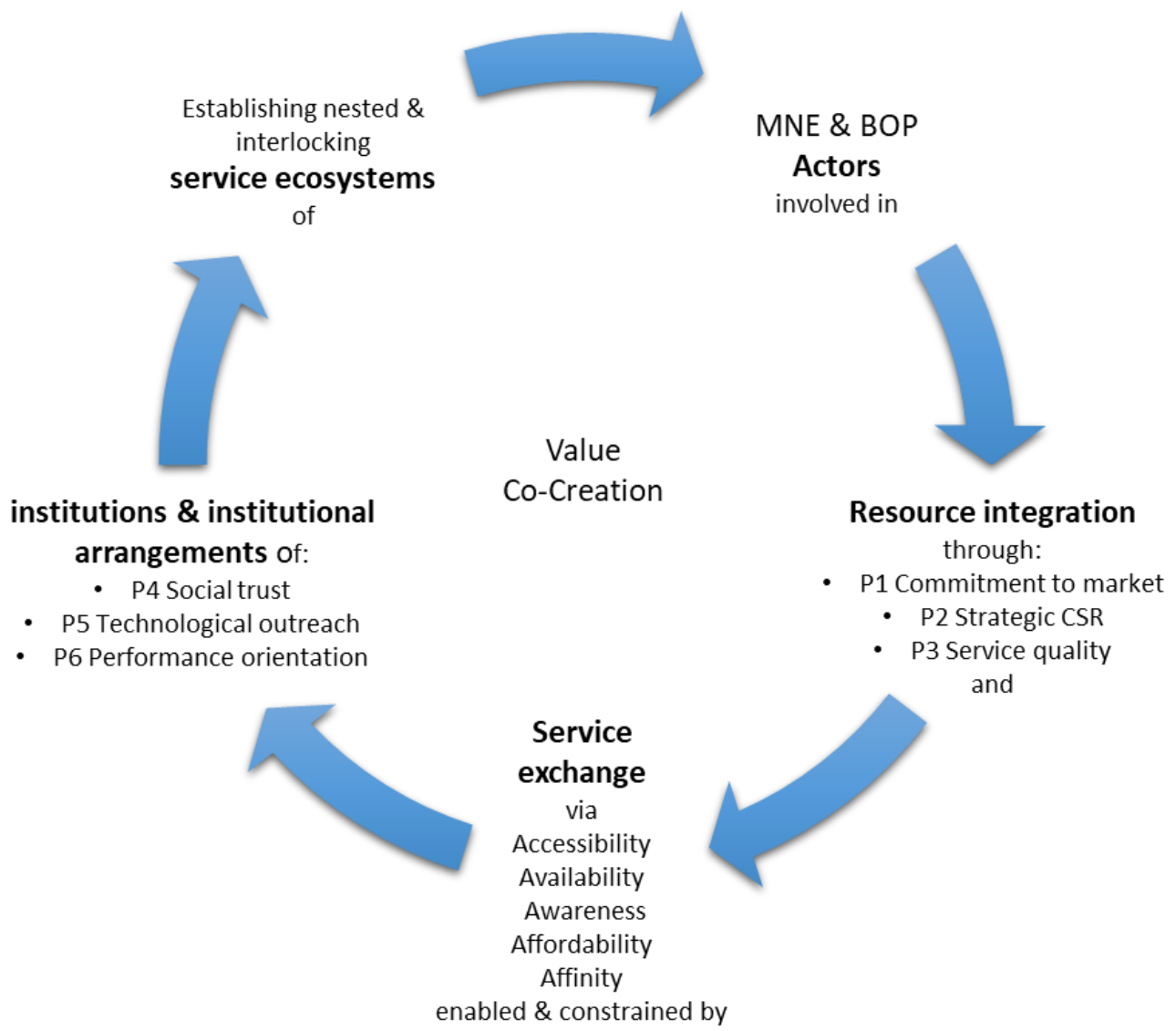

Figure 1 S-D logic narrative (adapted from Vargo \& Lusch, 2016) including propositions for BOP services marketing context

\section{Commitment to the Market}

MNE's have a chequered past in their commitment to BOP markets. The idea of vast numbers of consumers with unfulfilled needs is tantalising to any marketer worth their salt, but the reality of reaching these markets profitably has often proved harder than initially projected. This may result in a withdrawal from BOP markets, or in a decision to reach BOP markets through a CSR model rather than a business model. For example, in the case of Proctor and Gamble's PUR water purification powder, market research clearly indicated that the product fits an existing need in the market but disappointing results ultimately relegated it to a lossmaking category (Karamchandani et al., 2011).

The crucial importance of commitment is to foster trust in the customer base. Consumers in subsistence markets tend to be more suspicious of outsiders than in other markets, due to their vulnerable position and their lack of skill in evaluating market offers (Wood, Pitta and Franzak, 2008). Local businesses can leverage their existing social networks to engender trust but 
MNC's entering a new market have to put in the work to show they are committed to providing service in the long-term. Subsistence consumers lack the financial means to test new products and services on a trial and error basis so they tend to consider their purchasing decisions carefully (Chikweche, Stanton and Fletcher, 2012) and make choices based on experience of reliability (Beninger and Robson, 2015). New entrants will therefore have a harder task in proving they are worth the risk.

Interestingly, the basis of trust may not be on the ethical actions of the company. Trust based on social ties is utilised in transactions (Moser, 1998). Thus, local retail firms in India exhibiting multiple counts of unethical practices are still often favoured over large retail chains, mostly because of the level of their embeddedness in the neighbourhood's daily life, critical understanding of their needs, and a sense of identification consumers have with them (Gupta and Srivastava, 2016). The implication is therefore that commitment to the market is more than just providing offers to the market: it is about experiencing the market together with the customers.

While living the life of locals is not always an option for MNEs, strategic approaches can be taken to identify with the market. Contrasting the different strategic approaches taken by two financial companies shows that an aggressive approach to lending money to a struggling populace was initially successful for HSBC but ultimately led to regulative limitations, while HNB opted for long-term benefit by co-operating with local customers and ensuring lending would not drive them to a debt spiral (Elaydi and Harrison, 2010). While both firms showed commitment to the market through resource allocation and presence, HNB's approach was to embed itself in existing networks that ultimately allowed it to operate more freely and develop longevity in the market. Community involvement shows MNE's commitment to the market, which further leads to establishing local legitimacy, a key for long term success in BOP markets (Narwal and Singh, 2013). Moreover, involving local stakeholders in decision making conveys the message that the MNE is open and committed to responding to the needs of the local actors (Corus and Ozanne, 2012). Thus, we propose that:

Proposition 1 Commitment to the target BOP market tends to positively influence value creation in services marketing by the MNEs.

\section{Strategic CSR}


While, country-specific factors may create distance and uncertainty between the home and host country operations, firm-specific factors can be used to counter those (Yin and Jamali, 2016). CSR initiatives may be an indication of the company's general attitude or image towards doing good deeds, but strategic CSR actions on the ground level are the ones that truly have an impact on the people receiving them and can thus join the dual aims of making a profit and connecting socially (Husted et al., 2016). Thus, the MNE's motivation to offer services can also be reflected in their social activities.

CSR as a phenomenon has seen growing interest in the previous years, but the field still suffers from multiplicity of terms and approaches (Hah and Freeman, 2011). Much of the literature is focused on the expectation of MNEs offering non-economic programmes in addition to their profit-seeking operations, or the consequences of not operating ethically, but the CSR implementation of firms is especially lacking in definition (Lindgreen et al., 2009). Yet CSR can offer a powerful tool to companies seeking to maximise on their profit streams because it exemplifies their motivation to engage with the community rather than merely benefit from it.

A case of Barrick Gold Corporation by Newenham-Kahindi (2011) shows an example of a company applying CSR without fully understanding the strategic implications or the local conditions. While reaching out to the community and attempting to behave ethically, the company did not fully engage the local actors who consequently felt isolated and disengaged from involvement in local social projects. Moving towards strategic CSR and evaluating CSR activities in terms of co-creating value (Yin and Jamali, 2016) not only ensures the CSR activities are aligned with the company's primary objectives but also provides additional entry points to networks it might otherwise find difficult to access.

A call for more research on the influence of network actors on firm behaviour in the context of strategic CSR initiatives, has been raised by academics (Hustede et al., 2016). Such an approach can yield more information about the way CSR integrates with value creating activities such as services marketing (Hustede et al., 2016). The current book chapter recommends that strategic CSR is related to the company's motivation to create affinity through co-creative activities with the market but that its effect on service marketing goes also via the company's network embeddedness. Being present in networks of stakeholders with meaningful, engaging dialogues about social issues provides the company with knowledge about the needs of the market and ensures that value is experienced on both sides of the relationship. Based on this discussion, we propose that: 
Proposition 2 Strategic CSR activities in the target BOP market tend to positively influence value creation in services marketing by the MNEs.

\section{Service Quality}

There are fervent calls for more research about services in BOP markets (cf. Fisk et al., 2016) and studies in this arena have multiplied during our current decade. As even the basic level of offering services under the resource scarcity and unique network characteristics of BOP's is challenging, it is understandable that few studies qualify services not only as market-tailored company offers such as health care or financial services, but as value-laden relationships. Yet the failure rate of service offers in BOP markets suggests that what is offered to the market holds lesser significance than how it is offered.

The current book chapter uses service quality as a term for service offers that are relationship driven and customer oriented. Prior research in BOP microfinance suggests that service attributes are less likely to influence a customer's opinion of a company as a good corporate citizen than the individual treatment they receive in their exchange or relationship with personnel (Jose and Buchanan, 2013). Furthermore, perceptions of service quality and trust were found to influence repeated usage of mobile healthcare services designed to fit the needs of BOP markets (Akter et al., 2013). Yet marketers easily fall in to the assumption that all that is needed in subsistence markets is offering cheaper - inferior - products without a long-term brand building strategy (Chikweche and Fletcher, 2012). Companies that focus on developing services based on external knowledge about market characteristics may therefore face issues if they neglect forging market relationships.

Consumption below the poverty level is more focused on fulfilling certain needs but those needs are as varied and contextually bound as they are in any other markets (Subrahmanyan and Gomez-Arias, 2008). Modern technologies in communications and entertainment are just as widespread among subsistence consumers as innovations more critical for improvement of their living conditions (Weidner et al., 2010). The acceptance of new technologies has been found to be easier for customers who move from no technology to wireless applications without the intermediary phase of landlines (Prahalad, 2005). However, as consumers' choice is often limited by gaps in transportation, infrastructures and supply, and their ability to make those choices is hindered by illiteracy and consequent lack of skills and confidence, both the buyers and sellers must adjust and thus provide a more customised service (Viswanathan et al., 2010). 
The earlier example of subsistence consumers continuing to frequent a local grocery store despite unethical behaviour (Gupta and Srivastava, 2016) might belie the assertion that service quality is as important firm-level attribute for successfully selling services in BOP markets as network embeddedness. However, recent research has critiqued severely a traditional view of BOP consumers as passive recipients of aid and services (Gebauer and Reynoso, 2013) and rather views these vast markets as complex service ecosystems (Ben Letaifa and Reynoso, 2015). As such, service design should consider the customer's service needs from the holistic perspective of what the customer is trying to accomplish with the service and what other resources and offers they can integrate in order to co-create value specific to their unique situation (Fisk et al., 2016). Service quality is provided when the customer experiences the value not just as a consumer but as a person.

Being customer oriented and creating positive customer experiences through relationships are well acknowledged staples in service literature. The greater issue is in questioning assumptions many Western MNEs have about operating in BOP markets or with people below the poverty level (Chikweche and Fletcher, 2012; Gebauer and Reynoso, 2013). Poor people care about brands, about the social context of their purchases, and being awarded the dignity of choice and respect as any other customers do (Prahalad, 2005; Goyal et al., 2015). While the outwardly elements of service quality may differ in a subsistence market and Silicon Valley, ultimately successful services marketing requires responding to customer needs in a manner that engages the customer to co-create value for the solution. Based on this discussion, we propose that:

Proposition 3 Service quality in target BOP market tends to positively influence value creation in services marketing by the MNEs.

\section{Social Trust}

Social trust is a crucial informal institutional factor which influences information transmission, cooperation, and the enforcement of rules within a society (e.g. Kwon and Arenius, 2010; Ding et al., 2015). Social trust can further be referred as a resource that is available in abundance in many BOP markets, where consumers generally lack financial resources (e.g. Reficco and Marquez, 2014; Antalis, 2015). Consumers in BOP markets tend to have a high interdependence as well as they offer assistance to each other in need, due to lack of trust in their national institutions (e.g. Boin and Christensen, 2008; Ezhova et al., 2014). Some examples in this context include asking loans from social acquaintances and reliance on remittances from abroad sent by the relatives (Brinkerhoff, 2008; Antalis, 2015). Therefore, 
earlier research has found a paramount importance of reciprocal relationships and trust in such BOP markets for all activities of life (e.g. Frazier et al., 1989; Khayesi et al., 2014). Such reciprocal relationships have also been a key driver in buyer-seller relationship in both product as well as services sectors of BOP markets (Sridharan and Viswanathan, 2008; Antalis, 2015; Nakata and Antalis, 2015). For example, past research has referred to buyer trusting the information from business associates (Ding et al., 2015) or children or neighbours for buying new services or products (Sridharan and Viswanathan, 2008; Venugopal and Viswanathan, 2015). Moreover, researchers have referred to the importance of remittances (e.g. Antalis, 2015) to access services like healthcare, banking and insurance (Sridharan and Viswanathan, 2008; Martinez et al., 2015). Therefore, level of social trust has an important role in marketing strategies of all kind of business ventures in BOP markets (Davidsson and Honig, 2003; Goyer et al., 2014; Ding et al., 2015), as the potential buyer's behaviour is strongly linked to it.

It is important to mention that not all BOP markets have same level of social trust due to differences in history, social composition, diversity, political model, violence and other factors in these countries (Cassar et al., 2013; North et al., 2013; Howard, 2016). Earlier research has shown that MNEs tend to use to managerial ties as "executives' boundary spanning" activities to access key resources in new markets that not accessible otherwise (e.g. Geletkanycz and Hambrick, 1997; Peng and Luo, 2000). In case of BOP markets, such managerial ties and understanding of social dynamics (including trust) can assist MNEs to better address the potential customer needs (Pitta et al., 2008) as well as manage associated uncertainties (Li et al., 2014). For example, if an MNE is interested in selling health services in a BOP market, an understanding of social dynamics and trust can be helpful in linking the potential service offering with feasible delivery and financing options (e.g. Venugopal and Viswanathan, 2015). Similarly, an MNE interested in offering tailored financial services needs to understand some of BOP markets can be plagued by phenomenon of capital accumulation and conservative financial managements due to history of uncertainty linked to socio-political factors (e.g. Julian and Ofori-Dankwa, 2013; North et al., 2013; Howard, 2016). Hence, earlier research has shown that social trust can be relatively low in very restrictive economies as well as the ones that went through a range of political changes and violence (e.g. Cassar et al., 2013; North et al., 2013). This is primarily because these economies do not offer growth opportunities as individual entrepreneurs' access to financing due to conservative capital management, as well as lack of social trust leads to reduced information flow and subsequent cooperation. As, the states or monopolistic authorities, have a lot of power in such cases, they tend to discourage 
innovativeness as it leads to competition for them. Moreover, due to history of repression and conflict, social trust can also degrade thus leading to suspicion on new things including services (North et al., 2013; Howard, 2016). On the other hand, research has shown that social trust offers access to finance when intermediaries like banks are lacking (e.g. Roy et al., 2014). Moreover, social trust has also been found to offer assurances for business investors in economies, where legal systems are relatively weak (e.g. North et al, 2013; Kim and Li, 2015), leading to increased business activities (e.g. Bruhn and McKenzie, 2014; Robinson and Ritchie, 2016). Therefore, the presence of medium to high social trust can help MNEs to tailor their services offering keeping in view, customer requirements as well as not overstretching themselves financially. Based on this discussion, we propose that

Proposition 4 Social trust in the target BOP market tends to positively influence value creation in services marketing by the MNEs.

\section{Technological Outreach}

Technological outreach can be defined by the access of a country's population to electricity and telecommunication especially mobile and wireless communication technologies linked increasingly to internet (Rowles, 2017; Scott, 2017). Such technological outreach can be referred as a key driver for localised solution focused innovation as well as marketing of services and products in BOP markets (e.g. Berger and Nakata, 2013; Goyal et al., 2015). In many BOP market, mobile phone penetration has long overtaken fixed line phones, thereby removing the biggest hurdle to communication and access of services (e.g. Antalis, 2015; Goyal et al., 2015). However, along with focusing on mobile telephony usage at general level, as done in earlier studies, it is important to consider increased usage of relatively affordable smartphones, as well. Smartphones have resulted in millions getting cheaper access to internet, which was earlier difficult as buying a traditional computer with fixed internet connection was rather unaffordable (Foster and Heeks, 2013; Rowles, 2017). These smartphones further offer these consumers to advantage of portable technology offering them some kind of access to internet and for which there is less reliance on electricity (Berger and Nakata, 2013; Islam, 2016), as load shedding (breaks in continuous electricity supply), is a visible problem in BOP markets. Consumers in such BOP markets can use basic SMS services as well as smartphone apps to access services that were previously inaccessible to them (Tarafdar et al., 2012; ZhenWei Quiang, 2013; Antalis, 2015). It has been estimated that for every 10 percent of increase in mobile phone and technological penetration, there is economic growth of $0.8 \%$ in BOP 
markets (Zhen-Wei Quiang, 2013; Antalis, 2015). This increase in growth and resulting opportunities representing an important segment for services marketing for both local firms and MNEs.

Some earlier research has addressed the use of cheaper smart phones to deliver sophisticated and tailor made financial services (e.g. Tarafdar et al, 2012; Beger and Nakata, 2013; Rowles, 2017), healthcare services (e.g. Kapoor and Goyal, 2013), intermediary services for product exchange (e.g. Goyel et al., 2015; Islam, 2016) and supply chain management services (e.g. Scott and Tarafdar, 2014). However, so far most of these researchers have addressed the fact that how local firms and entrepreneurs have taken advantage of technological outreach to offer specialised services, rather than services marketing by MNEs. Research has further shown that there is increasing need of tailor made financial services like M-Pesa of Kenya or online bank account in BOP markets, where millions are still without access to "traditional" banking (Foster and Heeks, 2013; Berger and Nakata, 2013). Similarly, the demand for healthcare services especially in relation to information and prevention (Kapoor and Goyel, 2015; Deshpande et al., 2016) as well as agribusiness services (e.g. Chatterjee, 2016) and specialised supply chain services (Scott and Tarafdar, 2014; Khalid et al., 2015) are the areas, where there is a considerable demand and potential. Technological outreach is not limited to mobile and smartphones only, as access to electricity via localised production from different cheap and renewable sources are also important in BOP context (e.g. Lammi et al., 2015; Goyal et al., 2017). Lack of continuous electricity supply is a visible problem for many BOP consumers (Goyal et al., 2017; Scott, 2017).

Increasingly, for profit firms providing this service have tapped into this market by developing tailor made solutions including solar and wind energy (e.g. Scott, 2017). Once, electricity problem is resolved at localised level ensuring rather continuous supply, further opportunities for marketing for a range of other linked services including agribusiness, financing, healthcare and professional marketing services to promote local entrepreneurs, can potentially become open to market players including MNEs. Western MNEs can take advantage of prestige associated with foreign brand name (Angeli and Jaiswal, 2015; Gupta and Denblyker, 2015) while developing cheaper tailor made services to sell them to increased consumer segment available due to technological outreach. Therefore, technological outreach of a BOP market is a good indicator for an MNE to develop specific services fit to be sold in that context. Based on this discussion, we propose that 
Proposition 5 Technological outreach in the target BOP market tends to positively influence value creation in services marketing by the MNEs.

\section{Performance Orientation}

Culture has been one of the most researched factors in services marketing research (e.g. Webster, 1993; Grönroos, 2000; Wirtz and Lovelock, 2016). Culture has been defined in a variety of ways. However, a recent and rather comprehensive definition developed in the GLOBE project by Javidan et al. (2006: 899), defines national as "values beliefs, norms and behavioral patterns of a national group". Nine dimensions have been identified by GLOBE project include uncertainty avoidance, power distance, institutional collectivism, in-group collectivism, future orientation, performance orientation, humane orientation, assertiveness and gender egalitarianism. Out of all these dimensions of culture, performance orientation has been referred by earlier BOP focused studies as more applicable in that context (e.g. Antalis, 2015:767). Performance orientation of a society reflects "the societal differences in the definition and value of success, and shapes the way external challenges and inter-personal relationships are managed for achievement" (House et al., 2004: 27).

High performance oriented societies place emphasis on individual success and materialism, while low performance oriented ones, emphasize tradition above merit, and social harmony over personal gain (House et al., 2004: 245). Antalis (2015:767) has referred that medium to high performance orientation in a society can be specifically linked to creating business and selling activities, as it results in status, control, and economic benefits for the individuals there. Therefore, it is reasonable to expect that new services marketed by MNEs are influenced by this aspect, as in societies with limited economic opportunities, a new service can offer a unique competitive advantage to the user firms (e.g. Hojland and Rohrbeck, 2016). Earlier studies have shown that in high performance orientation societies, innovation and its acceptance is higher (e.g. Uzkurt et al., 2013; Chhokar et al., 2013). Moreover, some other researchers have found that citizens in high performance societies tend to adapt to new products sooner (e.g. Nakata and Weidner, 2012; Chhokar et al., 2013) and are more entrepreneurial in spirit (Antalis, 2015).

Based on GLOBE cultural scores, we can further observe a variance in BOP markets along this dimension as countries like Ecuador, Guatemala, Indonesia, Nigeria, and Philippines etc score medium to high (House et al., 2004: 251-252). However, consumers in some BOP markets like Bolivia and Venezuela score very low (House et al., 2004: 251-252) on the dimension of performance orientation, due to myriad of socio-cultural and political reasons. In this context, 
it is further important to mention that societies with relatively low performance orientation tend to emphasise tradition (House et al., 2004; Antalis, 2015). As, a result new services marketed by an MNE (potentially perceived to be an outsider) are expected to take relatively more time to gain consumer acceptance and confidence. This argument can be supported by referring to some earlier studies that addressed dynamics of consumer acceptance of foreign products in relatively traditional societies (e.g. Steenkamp and DeJong, 2010; Ferraro and Briody, 2017). However, as mentioned earlier, in case high performance oriented societies, acceptance and usage of new products and services is relatively fast faster, as these services are linked to potential economic benefits. Therefore, for western MNEs, marketing new, affordable and tailor made services in such markets can be successful, as they can complement their offering with links to prestige associated with a western brand as well (Angeli and Jaiswal, 2015; Schutte and Ciarlante, 2016). Based on this discussion, we propose that

Proposition 6 Performance orientation in the target BOP market culture tends to positively influence value creation services marketing by the MNEs.

\section{Conclusions and Implications}

The current book chapter aimed to address MNE, subsidiary and country level determinants of effective services marketing by MNEs in BOP markets. We adapted an approach where key determinants at MNE and subsidiary level were identified and discussed based on literature review. After that, we identified key country level (target BOP specific) determinants in discussion. This study offers several academic and managerial implications. Firstly, there is a general lack of services marketing in BOP focused research in academia, as the narrative is currently dominated by topics like frugal innovation, product marketing and micro finance. However, BOP markets represent increasingly an attractive and relatively untapped segment for MNEs especially when mature emerging markets have become saturated. Therefore, academic researchers should view and analyse BOP markets as a potential revenue source for MNEs, as well as potentially for SMEs, and address their different aspects of services marketing. Moreover, due to unique nature of market dynamics, there is a need by academia to engage in in-depth theory development, to increase the conceptual understanding of these important markets.

A key managerial implication of our book chapter is the view on BOP markets as a potential profit source for unique services by MNE managers, rather than only considering them for CSR 
activities, which has been the case earlier. Therefore, issues like service quality achieved by adaptability and affordability of offered services, as well as ensuring subsidiary's embeddedness in local networks to show commitment to market, are important for success. Moreover, it is important for the managers to differentiate between BOP markets especially based on their cultural characteristics like performance orientation, as well as aspects like social trust and technological outreach. Such differentiation can be helpful to avoid risk of developing generalised strategies for services marketing in BOP markets, which may lead to financially overstretching firm without significant returns or any value creation.

To illustrate the interplay between the different levels of factors at play in value creating relationships between foreign $\mathrm{MNE}$ and BoP market actors, Figure 2 shows the micro-macro continuum as the socio-cultural spectrum, which is influenced by firm interventions. Thus, we attempt to show that firms can take affirmative actions to influence their success in the marketplace, but as all markets are unique, there is no one-size-fits-all solutions.

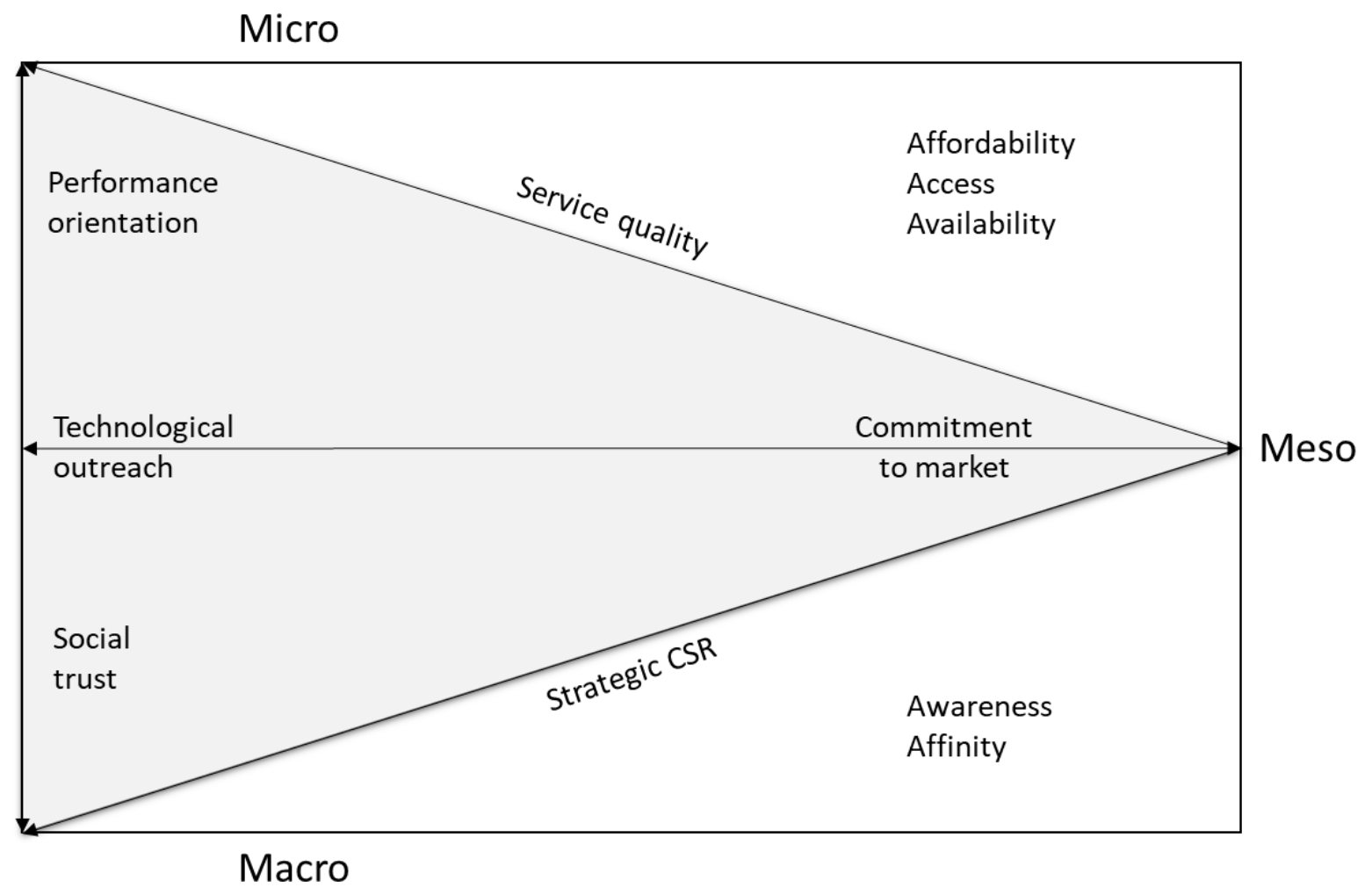

Figure 2 The micro-meso-macro continuum of determinants affecting services marketing in BOP markets

Our book chapter has several limitations. As it is conceptual, it aims to bring together multiple streams of literature. Therefore, it lacks the use of a specific theoretical background. Therefore, 
future studies may consider either adjusting current theoretical paradigms and engage in theory development to address dynamics of services marketing in BOP markets. Secondly, the current book chapter lacks empirical analysis, and hence, presented propositions are not tested and generalised. Both quantitative and qualitative studies are needed in context of BOP markets to understand determinants of services marketing, and future studies can address this aspect. Finally, the current book chapter address "services" rather generically, and does not differentiate based on differences in different kind of services. However, future studies can adapt a more focused approach and specifically address marketing determinants of different kinds of services like banking, insurance, and healthcare.

\section{References}

Abdelnour, S., \& Branzei, O. (2010). Fuel-efficient stoves for Darfur: The social construction of subsistence marketplaces in post-conflict settings. Journal of Business Research, 63(6), 617629.

Akter, S., Ray, P., \& D'Ambra, J. (2013). Continuance of mHealth services at the bottom of the pyramid: the roles of service quality and trust. Electronic Markets, 23(1), 29-47.

Anderson, J. L., Markides, C., \& Kupp, M. (2010). The last frontier: Market creation in conflict zones, deep rural areas, and urban slums. California Management Review, 52(4), 6-28.

Angeli, F., \& Jaiswal, A. K. (2015). Competitive dynamics between MNCs and domestic companies at the base of the pyramid: An institutional perspective. Long Range Planning, 48(3), 182-199.

Antalis, E. (2015). Enhancing market exchanges at the base of the pyramid. International Marketing Review, 32(6), 762-782.

Ben Letaifa, S., \& Reynoso, J. (2015). Toward a service ecosystem perspective at the base of the pyramid. Journal of Service Management, 26(5), 684-705.

Beninger, S., \& Robson, K. (2015). Marketing at the base of the pyramid: Perspectives for practitioners and academics. Business Horizons, 58(5), 509-516.

Berger, E., \& Nakata, C. (2013). Implementing technologies for financial service innovations in base of the pyramid markets. Journal of Product Innovation Management, 30(6), 1199-1211.

Boin, A., \& Christensen, T. (2008). The development of public institutions reconsidering the role of leadership. Administration \& Society, 40(3), 271-297.

Brenes, E. R., Montoya, D., \& Ciravegna, L. (2014). Differentiation strategies in emerging markets: The case of Latin American agribusinesses. Journal of Business Research, 67(5), 847-855.

Brinkerhoff, D. W. (2008). The state and international development management: Shifting tides, changing boundaries, and future directions. Public Administration Review, 68(6), 985-1001.

Bruhn, M., \& McKenzie, D. (2014). Entry regulation and the formalization of microenterprises in developing countries. The World Bank Research Observer, 29(2), 186-201.

Cassar, A., Grosjean, P., \& Whitt, S. (2013). Legacies of violence: trust and market development. Journal of Economic Growth, 18(3), 285-318.

Chhokar, J. S., Brodbeck, F. C., \& House, R. J. (Eds.). (2013). Culture and leadership across the world: The GLOBE book of in-depth studies of 25 societies. London: Routledge.

Crawford-Mathis, K., Darr, S., \& Farmer, A. (2010). The Village Network ${ }^{\mathrm{TM}}$ : Partnership and collaboration to alleviate poverty in subsistence marketplaces. Journal of Business Research, 63(6), 639-642.

Cruz, P., Barretto Filgueiras Neto, L., Muñoz-Gallego, P., \& Laukkanen, T. (2010). Mobile banking rollout in emerging markets: Evidence from Brazil. International Journal of Bank Marketing, 28(5), 342-371. 
Chatterjee, S. R. (2016). Rethinking business models for flexible configuration: Lessons from disruptive innovation at the bottom of the pyramid (BOP). In Sushil, J. Connel, \& J. Burgess (Eds.) Flexible Work Organizations: The challenges of capacity building in Asia, (pp. 181193). New Delhi: Springer India.

Chikweche, T., \& Fletcher, R. (2010). Understanding factors that influence purchases in subsistence markets. Journal of Business Research, 63(6), 643-650.

Chikweche, T., Stanton, J., \& Fletcher, R. (2012). Family purchase decision making at the bottom of the pyramid. Journal of Consumer Marketing, 29(3), 202-213.

Corus, C., \& Ozanne, J. L. (2012). Stakeholder engagement: Building participatory and deliberative spaces in subsistence markets. Journal of Business Research, 65(12), 1728-1735.

Davidsson, P., \& Honig, B. (2003). The role of social and human capital among nascent entrepreneurs. Journal of business venturing, 18(3), 301-331.

Deshpande, A., Mathur, A., \& Krishnamurthy, S. (2016). Application of Internet of Things in healthcare sector for bottom of pyramid in India. International Journal of Engineering Applied Sciences and Technology, l(11), 28-33.

Ding, Z., Au, K., \& Chiang, F. (2015). Social trust and angel investors' decisions: A multilevel analysis across nations. Journal of Business Venturing, 30(2), 307-321.

Elaydi, R., \& Harrison, C. (2010). Strategic motivations and choice in subsistence markets. Journal of Business Research, 63(6), 651-655.

Ezhova, I., Bruton, G. D., \& Webb, J. W. (2014). Trust, formality, and performance in base-of-thepyramid markets. Academy of Management Proceedings, 1, 167-190.

Ferraro, G. P., \& Briody, E. K. (2017). The cultural dimension of global business. Oxon: Taylor \& Francis.

Foster, C., \& Heeks, R. (2013). Conceptualising inclusive innovation: Modifying systems of innovation frameworks to understand diffusion of new technology to low-income consumers. The European Journal of Development Research, 25(3), 333-355.

Frazier, G. L., Gill, J. D., \& Kale, S. H. (1989). Dealer dependence levels and reciprocal actions in a channel of distribution in a developing country. The Journal of Marketing, 53(1), 50-69.

Geletkanycz, M. A. and Hambrick, D. C. 1997. The external ties of top executives: Implications for strategic choice and performance. Administrative Science Quarterly, 42(4): 654-81.

Goyal, S., Sergi, B. S., \& Jaiswal, M. (2015). How to design and implement social business models for base-of-the-pyramid (BOP) markets? The European Journal of Development Research, 27(5), 850-867.

Goyal, S., Sergi, B. S., \& Kapoor, A. (2017). Emerging role of for-profit social enterprises at the base of the pyramid: the case of Selco. Journal of Management Development, 36(1), 97-108.

Gebauer, H., \& Reynoso, J. (2013). An agenda for service research at the base of the pyramid. Journal of Service Management, 24(5), 482-502.

Gronroos, C. (1990). Relationship approach to marketing in service contexts: The marketing and organizational behavior interface. Journal of Business Research, 20(1), 3-11.

Grönroos, C. (2012). Conceptualising value co-creation: A journey to the 1970s and back to the future. Journal of Marketing Management, 28(13-14), 1520-1534.

Gutiérrez, R., \& Vernis, A. (2016). Innovations to serve low-income citizens: When corporations leave their comfort zones. Long Range Planning, 49(3), 283-297.

Gupta, S., \& Denbleyker, C. (2015). An exploratory investigation of deal proneness at the bottom of the pyramid. Academy of Marketing Studies, 19(2), 49-63.

Gupta, S., \& Srivastava, P. (2016). Despite unethical retail store practices, consumers at the bottom of the pyramid continue to be loyal. The International Review of Retail, Distribution and Consumer Research, 26(1), 75-94.

Hah, K., \& Freeman, S. (2014). Multinational enterprise subsidiaries and their CSR: A conceptual framework of the management of CSR in smaller emerging economies. Journal of Business Ethics, 122(1), 125-136.

Helliwell, J. F., Huang, H., \& Wang, S. (2015). The geography of world happiness. In Helliwell, J. F., R. Layard \& J. Sachs (Eds.) World Happiness Report, (pp. 12-41). New York: Sustainable Development Solutions Network. 
House, R. J., Hanges, P. J., Javidan, M., Dorfman, P. W., \& Gupta, V. (2004). Culture, leadership, and organizations: The GLOBE study of 62 societies. Thousand Oaks, CA: Sage Publications.

Højland, J., \& Rohrbeck, R. (2016). The role of corporate foresight in exploring new markets-evidence from 3 case studies in the BOP markets. Technology Analysis and Strategic Management, 30(6), 734-746.

Howard, T. (2016). Failed states and the origins of violence: A comparative analysis of state failure as a root cause of terrorism and political violence. Oxon: Routledge.

Husted, B. W., Jamali, D., \& Saffar, W. (2016). Near and dear? The role of location in CSR engagement. Strategic Management Journal. 37(10), 2050-2070.

Islam, T. (2016). Emergence, opportunities and challenges of online marketing in Bangladesh: An observational review. South Asian Journal of Marketing \& Management Research, 6(9), 1-18.

Jacob, F., \& Ulaga, W. (2008). The transition from product to service in business markets: An agenda for academic inquiry. Industrial marketing management, 37(3), 247-253.

Javidan, M., House, R. J., Dorfman, P. W., Hanges, P. J., \& De Luque, M. S. (2006). Conceptualizing and measuring cultures and their consequences: a comparative review of GLOBE's and Hofstede's approaches. Journal of international business studies, 37(6), 897-914.

Julian, S. D., \& Ofori-dankwa, J. C. (2013). Financial resource availability and corporate social responsibility expenditures in a sub-Saharan economy: The institutional difference hypothesis. Strategic Management Journal, 34(11), 1314-1330.

Kapoor, A., \& Goyal, S. (2013). Inclusive healthcare at base of the pyramid (BOP) in India. International Journal of Trade and Global Markets, 6(1), 22-39.

Kang, D. S., \& Kang, D. S. (2016). Turning inside out: perceived internal branding in customer-firm relationship building. Journal of Services Marketing, 30(4), 462-475.

Karamchandani, A., Kubzansky, M., \& Lalwani, N. (2011). Is the bottom of the pyramid really for you. Harvard Business Review, 89(3), 107-111.

Khalid, R. U., Seuring, S., Beske, P., Land, A., Yawar, S. A., \& Wagner, R. (2015). Putting sustainable supply chain management into base of the pyramid research. Supply Chain Management: An International Journal, 20(6), 681-696.

Khanna, T., \& Palepu, K. G. (2010). Winning in emerging markets: A road map for strategy and execution. Boston: Harvard Business Press.

Khayesi, J. N., George, G., \& Antonakis, J. (2014). Kinship in entrepreneur networks: Performance effects of resource assembly in Africa. Entrepreneurship Theory and Practice, 38(6), 13231342.

Kim, P. H., \& Li, M. (2014). Seeking assurances when taking action: Legal systems, social trust, and starting businesses in emerging economies. Organization Studies, 35(3), 359-391.

Kolk, A., Rivera-Santos, M., \& Rufín, C. (2014). Reviewing a decade of research on the "base/bottom of the pyramid" (BOP) concept. Business \& Society, 53(3), 338-377.

Kravets, O., \& Sandikci, O. (2014). Competently ordinary: New middle class consumers in the emerging markets. Journal of Marketing, 78(4), 125-140.

Li, Y., Chen, H., Liu, Y., \& Peng, M. W. (2014). Managerial ties, organizational learning, and opportunity capture: A social capital perspective. Asia Pacific Journal of Management, 31(1), 271-291.

Martinez, C., Cummings, M. E., \& Vaaler, P. M. (2015). Economic informality and the venture funding impact of migrant remittances to developing countries. Journal of Business Venturing, 30(4), 526-545.

Moser, C. (1998). Reassessing urban poverty reduction strategies: The asset vulnerability framework. World development, 26(1), 1-19.

Nakata, C., \& Weidner, K. (2012). Enhancing new product adoption at the base of the pyramid: a contextualized model. Journal of Product Innovation Management, 29(1), 21-32.

Narwal, M., \& Singh, R. (2013). Corporate social responsibility practices in India: a comparative study of MNCs and Indian companies. Social Responsibility Journal, 9(3), 465-478.

Newenham-Kahindi, A. M. (2011). A global mining corporation and local communities in the lake Victoria zone: The case of Barrick Gold multinational in Tanzania. Journal of Business Ethics, 99(2), 253-282. 
North, D. C., Wallis, J. J., Webb, S. B., \& Weingast, B. R. (Eds.). (2013). In the shadow of violence: Politics, economics, and the problems of development. Cambridge: Cambridge University Press.

Pansera, M., \& Owen, R. (2015). Framing resource-constrained innovation at the 'bottom of the pyramid': Insights from an ethnographic case study in rural Bangladesh. Technological Forecasting and Social Change, 92, 300-311.

Reficco, E., \& Márquez, P. (2012). Inclusive networks for building BOP markets. Business \& Society, 51(3), 512-556.

Rohatynskyj, M. (2011). Development discourse and selling soap in Madhya Pradesh, India. Human Organization, 70(1), 63-73.

Rubalcaba, L., Aboal, D., \& Garda, P. (2016). Service innovation in developing economies: Evidence from Latin America and the Caribbean. The Journal of Development Studies, 52(5), 607-626.

Schuster, T., \& Holtbrügge, D. (2012). Market entry of multinational companies in markets at the bottom of the pyramid: A learning perspective. International Business Review, 21(5), 817-830.

Scott, N., \& Tarafdar, M. (2014). Impact of information technology deployment on supply chains at the bottom of pyramid: A separations lens. Available online http://aisel.aisnet.org/globdev2014/5

Scott, I. (2017). A business model for success: Enterprises serving the base of the pyramid with offgrid solar lighting. Renewable and Sustainable Energy Reviews, 70, 50-55.

Schütte, H., \& Ciarlante, D. (2016). Consumer behaviour in Asia. London: Macmillan Press.

Simanis, E., \& Hart, S. L. (2009). Innovation from the inside out. MIT Sloan Management Review, 50(4), 77.

Simanis, E., \& Milstein, M. (2012). Back to business fundamentals: Making "bottom of the pyramid" relevant to core business. Field Actions Science Report, 4(Special Issue), 82-88.

Sridharan, S., \& Viswanathan, M. (2008). Marketing in subsistence marketplaces: consumption and entrepreneurship in a South Indian context. Journal of Consumer Marketing, 25(7), 455-462.

Steenkamp, J. B. E., \& de Jong, M. G. (2010). A global investigation into the constellation of consumer attitudes toward global and local products. Journal of Marketing, 74(6), 18-40.

Subrahmanyan, S., \& Tomas Gomez-Arias, J. (2008). Integrated approach to understanding consumer behavior at bottom of pyramid. Journal of Consumer Marketing, 25(7), 402-412.

Tarafdar, M., Anekal, P., \& Singh, R. (2012). Market development at the bottom of the pyramid: examining the role of information and communication technologies. Information Technology for Development, 18(4), 311-331.

Orel, F. D., \& Kara, A. (2014). Supermarket self-checkout service quality, customer satisfaction, and loyalty: Empirical evidence from an emerging market. Journal of Retailing and Consumer Services, 21(2), 118-129.

Peng, M. W., \& Luo, Y. (2000). Managerial ties and firm performance in a transition economy: The nature of a micro-macro link. Academy of Management Journal, 43(3), 486-501.

Peterson, M., Ekici, A., \& Hunt, D. M. (2010). How the poor in a developing country view business' contribution to quality-of-life 5years after a national economic crisis. Journal of Business Research, 63(6), 548-558.

Pitta, D. A., Guesalaga, R., \& Marshall, P. (2008). The quest for the fortune at the bottom of the pyramid: potential and challenges. Journal of Consumer Marketing, 25(7), 393-401.

Prahalad, C. K. (2005). The fortune at the bottom of the pyramid: Eradicating poverty through profits. Vikalpa, 30(2), 149-154.

Prahalad, C. K. (2012). Bottom of the Pyramid as a Source of Breakthrough Innovations. Journal of Product Innovation Management, 29(1), 6-12.

Robison, L. J., \& Ritchie, B. K. (2016). Relationship economics: The social capital paradigm and its application to business, politics and other transactions. Oxon: Routledge.

Rowles, D. (2017). Mobile marketing: how mobile technology is revolutionizing marketing, communications and advertising. London: Kogan Page Publishers.

Sehgal, V., Dehoff, K., \& Panneer, G. (2010). The innovators - The importance of frugal engineering providing new goods and services to "bottom of the pyramid" customers requires a radical rethinking of product development. Strategy and Business, 59(1), 20-37.

Sheth, J., \& Sisodia, R. (2012). The 4 A's of marketing: Creating value for customer, company and society. Oxon: Routledge. 
Sinkovics, N., Sinkovics, R. R., \& Yamin, M. (2014). The role of social value creation in business model formulation at the bottom of the pyramid-implications for MNEs? International Business Review, 23(4), 692-707.

Valente, M., \& Crane, A. (2010). Public responsibility and private enterprise in developing countries. California Management Review, 52(3), 52-78.

Vargo, S.L. \& Lusch, R.F. (2016). Institutions and axioms: an extension and update of service-dominant logic. Journal of the Academy of Marketing Science, 44, 5-23.

Venugopal, S., \& Viswanathan, M. (2015). Developing customer solutions for subsistence marketplaces in emerging economies: a bottom-up 3C (customer, community, and context) approach. Customer Needs and Solutions, 2(4), 325-336.

Viswanathan, M., Sridharan, S., \& Ritchie, R. (2010). Understanding consumption and entrepreneurship in subsistence marketplaces. Journal of Business Research, 63(6), 570-581.

Weidner, K. L., Rosa, J. A., \& Viswanathan, M. (2010). Marketing to subsistence consumers: Lessons from practice. Journal of Business Research, 63(6), 559-569.

Wirtz, J., \& Lovelock, C. (2016). Services marketing: People, technology, strategy. London: World Scientific Publishing Co. Inc.

Wood, V. R., Pitta, D. A., \& Franzak, F. J. (2008). Successful marketing by multinational firms to the bottom of the pyramid: connecting share of heart, global "umbrella brands", and responsible marketing. Journal of Consumer Marketing, 25(7), 419-429.

Yin, J., \& Jamali, D. (2016). Strategic corporate social responsibility of multinational companies subsidiaries in emerging markets: Evidence from China. Long Range Planning, 49(5), 541-558.

Zhen-Wei Qiang, C. (2013). Telecommunications and Economic Growth, Washington, D.C.: World Bank Papers. 